Notes on Jebel Marra, Darfur

Author(s): H. F. C. Hobbs

Source: The Geographical Journal, Vol. 52, No. 6 (Dec., 1918), pp. 357-363

Published by: geographicalj

Stable URL: http://www.jstor.org/stable/1780270

Accessed: 22-06-2016 01:32 UTC

Your use of the JSTOR archive indicates your acceptance of the Terms \& Conditions of Use, available at

http://about.jstor.org/terms

JSTOR is a not-for-profit service that helps scholars, researchers, and students discover, use, and build upon a wide range of content in a trusted digital archive. We use information technology and tools to increase productivity and facilitate new forms of scholarship. For more information about JSTOR, please contact support@jstor.org.

The Royal Geographical Society (with the Institute of British Geographers), Wiley are collaborating with JSTOR to digitize, preserve and extend access to The Geographical Journal 
supplied by the local shaikhs under political arrangements. This enabled local information to be more readily obtained and ensured economy in the use of military escorts and transport, which could ill be spared from their duties elsewhere.

The large amount of survey carried out since December I9I4 could not have been done without the co-operation and great help given by the officers of the General Staff in Mesopotamia, and especially by the Intelligence and Political Departments, nor without the personal interest taken in the work by the late Army Commander, Lieut.-General Sir Stanley Maude, K.C.B., C.M.G., D.S.o.

The difficulties experienced in carrying out surveys in Mesopotamia during the three and a quarter years they were under the direction of Colonel Pirrie were in the employment of officers and surveyors on particular work suitable to their individual qualifications and experience, and to anticipate correctly the probable course of events and to increase promptly the survey establishment by adequate and suitable reinforcements, and to carry out and complete in the time available sufficiently accurate surveys for particular purposes, and by irregular and rapid methods, if necessary, and at the same time to keep the work as a whole scientifically controlled and up to the high standard of the Survey of India.

\title{
NOTES ON JEBEL MARRA, DARFUR
}

\section{Captain H. F. C. Hobbs, The Prince of Wales' Own (West Yorkshire Regiment), attached Egyptian Army}

\begin{abstract}
$\mathrm{J}^{\mathrm{m}}$ EBEL Marra, in Darfur, although marked on almost any small-scale map of Africa that one cares to examine, is a mountain-or, more correctly speaking, a tangled mass of mountains-about which little is known and of which none but very approximate and inaccurate smallscale maps exist. As far as I am aware, the south-westerly peak of the Jebel and the two small lakes which lie close to it, which I am about to describe, have never before been visited by a European; although the lakes were evidently known by repute, since they appear as "See Daribe" on Nachtigal's map (Justus Perthes, 1875). I believe that Zubeir Pasha, sometime in the seventies, paid a visit to these lakes, but the local natives say that he never climbed the peak.

Our duties on a patrol in Southern Darfur, in March rgr8, gave Mr. J. A. Gillan, of the Sudan Civil Service, and myself an opportunity of making a very brief exploration of the above places. Our starting-point was from the Fur village of Kallokiting, which lies at the base of the southwesterly foothills of the mountain, about 90 miles south-west of El Fasher. The lakes and peak lie, as the crow flies, some 20 miles N.N.W.
\end{abstract}




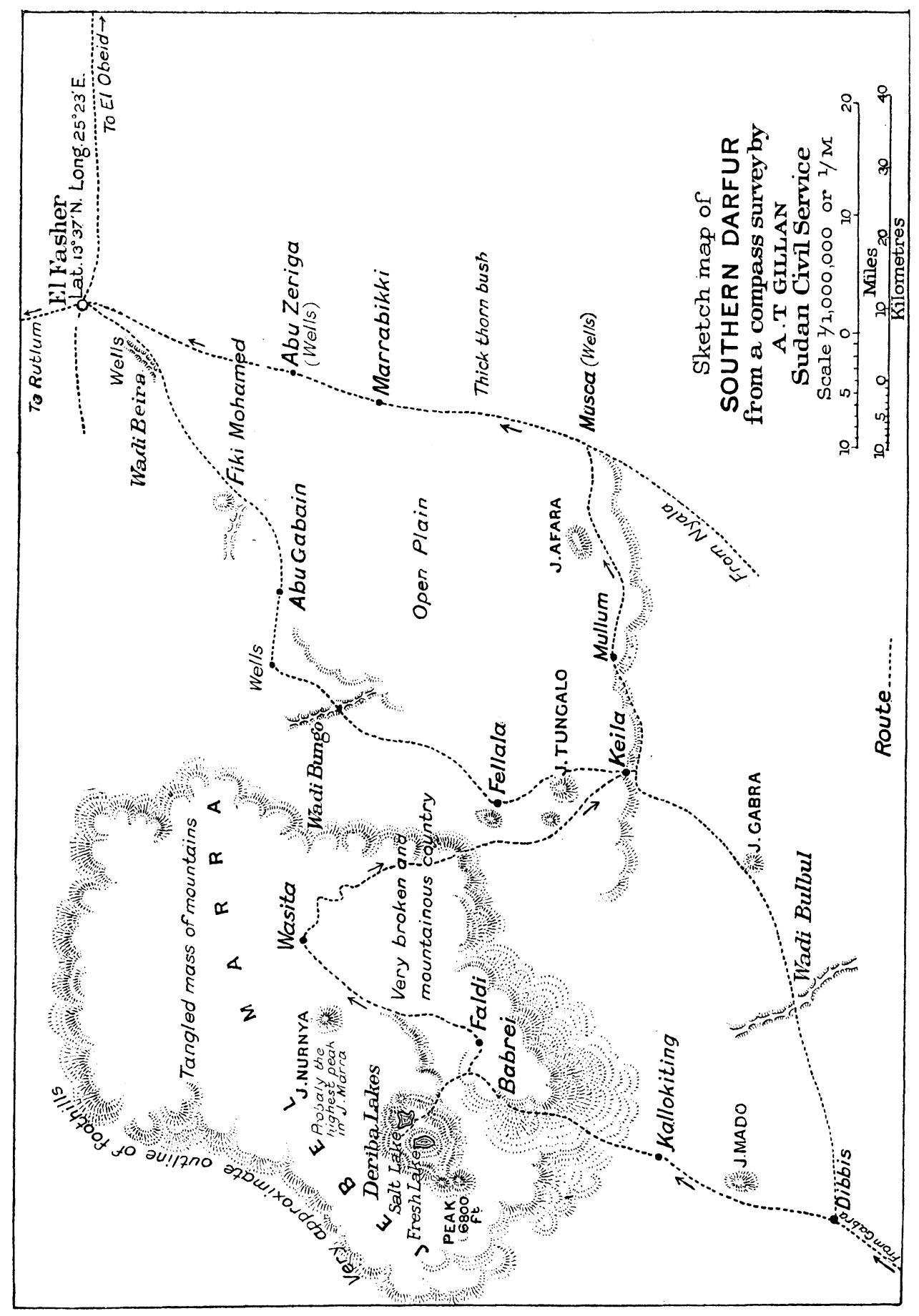


of this village, the route on foot to the former being nearly 30 miles, and to the latter, by the track we followed, about 40 miles. Leaving Kallokiting early on March II we camped the same night at an altitude of 2000 feet above the plain, reaching the lakes at Deriba the following morning. The going throughout was very broken and difficult, and in places a false step would have meant a fall of several hundreds of feet. There appeared to be few obstacles, however, which could not be successfully negotiated by our transport donkeys; the way in which these animals-born and bred on the mountain-sides-carried our loads over the seemingly most impossible obstructions was truly extraordinary. The lower slopes of the mountain are very rugged and barren in this locality, although the sides of almost every spur and re-entrant had long since been terraced for cultivation purposes, the result of years of labour, and

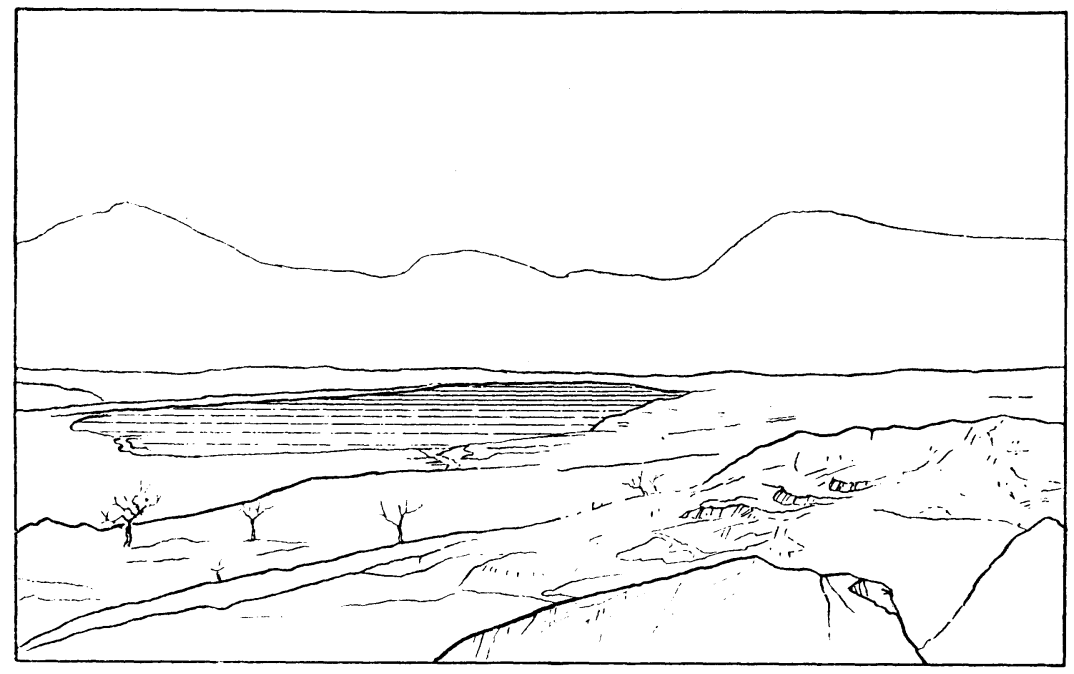

THE SALT LAKE LOOKING NORTH-WEST

(Drazen from photograph by the Author.)

indicative of a very numerous and, it would appear, industrious population in former times. It was not until we had risen some I 700 feet above the plain that we encountered any signs of present-day occupation : here the nature of the country changes, numerous rock-plants, bracken, and short grass making their appearance with villages, areas of wheat cultivation, and tomato and onion patches; the latter being irrigated by means of the many small running streams with which the Jebel abounds.

The two lakes at Deriba (as far as I am aware, the only two in Jebel Marra) lie, at an altitude of 1700 feet above the plain and 4804 feet above sea-level, in the arena of what may best be described as a vast amphitheatre, from 3 to 4 miles in diameter, formed by a continuous circular (or slightly oval) range of steeply sloping heights, varying from about 800 to 2000 feet above the surface of the lakes. 
The salt lake (termed by the natives the "female"), which is the larger of the two, occupies the north-east corner of this amphitheatre. It measures approximately $195^{\circ}$ yards in length, $135^{\circ}$ in breadth and about $3 \frac{1}{4}$ miles in circumference. The water is very salt, dirty, greenish in colour and has an unpleasant, acrid smell. There is a very heavy deposit of salt all round the perimeter of the lake, clearly defining its high-water mark. Except at the northern end the banks shelve very gradually into soft, oozing, strongly smelling mud. I had no time to take soundings; but from the gently sloping nature of the banks and the ground in their immediate vicinity, it would appear that the lake is of no great depth, except, possibly, at its extreme northerly end. I made a complete prismatic compass traverse of this lake, pacing the distances. My closing error being small, I think the results are fairly accurate.

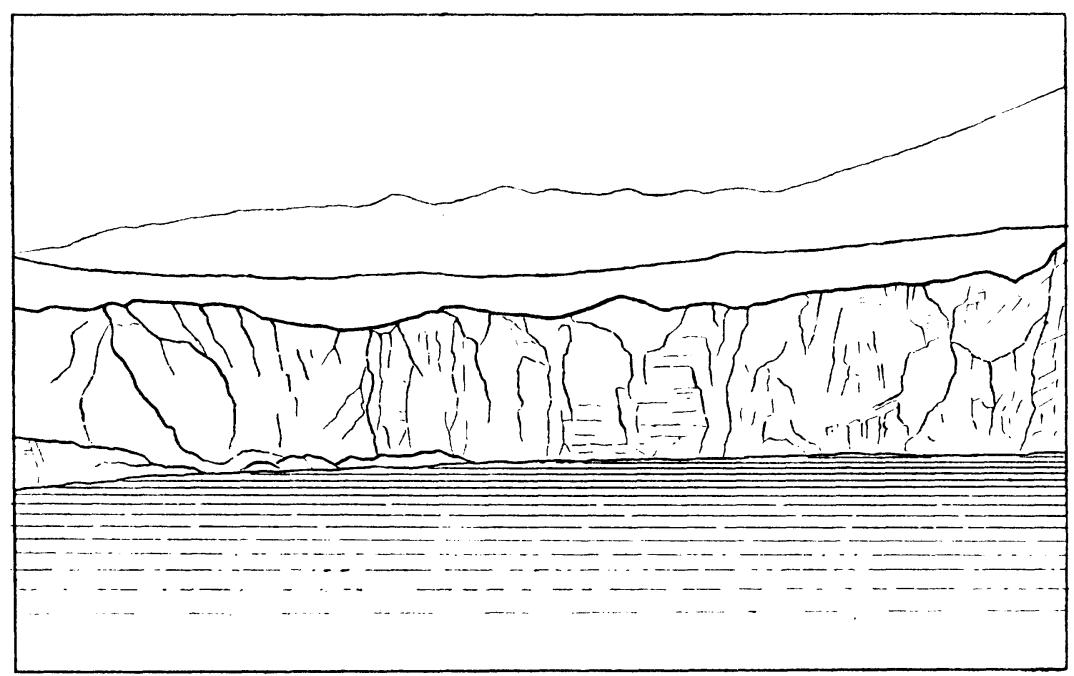

THE CRATER LAKE LOOKING DUE WFST

(Drawn from photograph by the Author.)

The second lake (the "male") lies about $\frac{3}{4}$ mile to the south-west of the salt lake and contains more or less fresh water. It is approximately I550 yards long, 900 broad, with a circumference of about 2 miles. It forms the centre of a large crater, undoubtedly volcanic in origin, the sides of which rise almost perpendicularly out of the water to heights varying from about 400 to 700 feet, except on the northern side, where the lip of the crater is considerably lower than on the other sides, and where the slope to the water is more gradual. The water, like that of the salt lake, is greenish in colour, but clean and clear, and smells and tastes slightly of sulphur. Mr. Gillan obtained a bottleful of this water with the intention of sending it to Khartoum for analysis, but it was unfortunately broken, incidentally with our last bottle of whiskey, next day. The banks shelve very abruptly and the lake appears to be of great depth. 
I had no time to take soundings or to make a complete traverse of this lake, and had to rely on a prismatic compass and a pocket range-finder for most of my distances; the figures given above must therefore be considered as only approximate.

The lake is regarded with much superstition and fear by the inhabitants of Jebel Marra, to whom its mystic properties are well known, though extraordinarily few natives appear to have actually visited it. The Furs of the Jebel say it is haunted, regard it as an oracle, and ask it questions, the answers to which they deduce from the various colours which the waters of the lake assume in the early morning or late afternoon, when there is considerable reflection, or when the surface of the water is ruffled by the wind. When Ali Dinar, the late Sultan of Darfur, was fleeing in front of the force under Major (now Brigadier-General) H. J. Huddleston, D.s.o., in October 19I6, he sent two of his followers to this lake to consult the waters on his future movements. The natives say the "waters refused" to let the envoys approach, and even retired before them, which probably means that the latter became panic stricken and were too terrified to go near the water. Whatever happened did not do Ali Dinar much good, as he was killed and the whole of his forces taken prisoners a few weeks later. Mr. Gillan and myself and several of the native soldiers and police who had accompanied us on this trip bathed in the lake, in view of some of the Jebel sheikhs, who were much impressed when they saw us all emerge safely from the water, unharmed by the demons of the lake. Nothing would induce any of them to bathe, though a few of the more venturesome timidly washed their faces and hands.

There is no outlet of any kind from either of these lakes, unless it be subterranean. They are fed by numerous khors from the surrounding mountains, only one of which was running on the date of our visit (13 March r9i8). It is worth noting that there appears to be very little rise or fall of water in either of the lakes. As I have mentioned, the high-water mark of the salt lake was very clearly defined and was certainly not more than 2 feet above the level of the water as we saw it. This is rather remarkable, as an enormous quantity of water must come down from the encircling mountains in the rainy season.

We made the ascent of the main south-westerly peak (marked A on sketch-map) on March $\mathbf{1} 3$. The previous evening we assembled the majority of the natives who had accompanied us from Kallokiting, together with several who lived near the lakes, with a view to obtaining guides to show us the best way up the mountain. Trusting, no doubt, that by feigning ignorance of the way they might deter the incomprehensible white men from attempting not only an unnecessary but a distinctly fatiguing expedition, the natives, one and all, said there was no path and that if there was they did not know it. We replied that we did not want a path and that we would find a way up, and added that, in order to give them an opportunity of learning a little of the geography of their 
own mountain, they had all better accompany us next day. When we set out next morning, however, several guides were forthcoming, who led us at once on to a well-worn track which took us over the worst part of our climb. From the lake-level the ascent occupied $4 \frac{3}{4}$ hours, the climb up the face of the heights encircling the lakes being almost precipitous. Having gained the crest of these heights, we found that our best way was to move along it, which we did, and reached our objective without difficulty. Having reached the summit, where a cairn was built, we found that there were two other peaks, about $\frac{1}{2}$ mile and 4 miles distant respectively (marked B and C on sketch-map), which were higher by 50 or 100

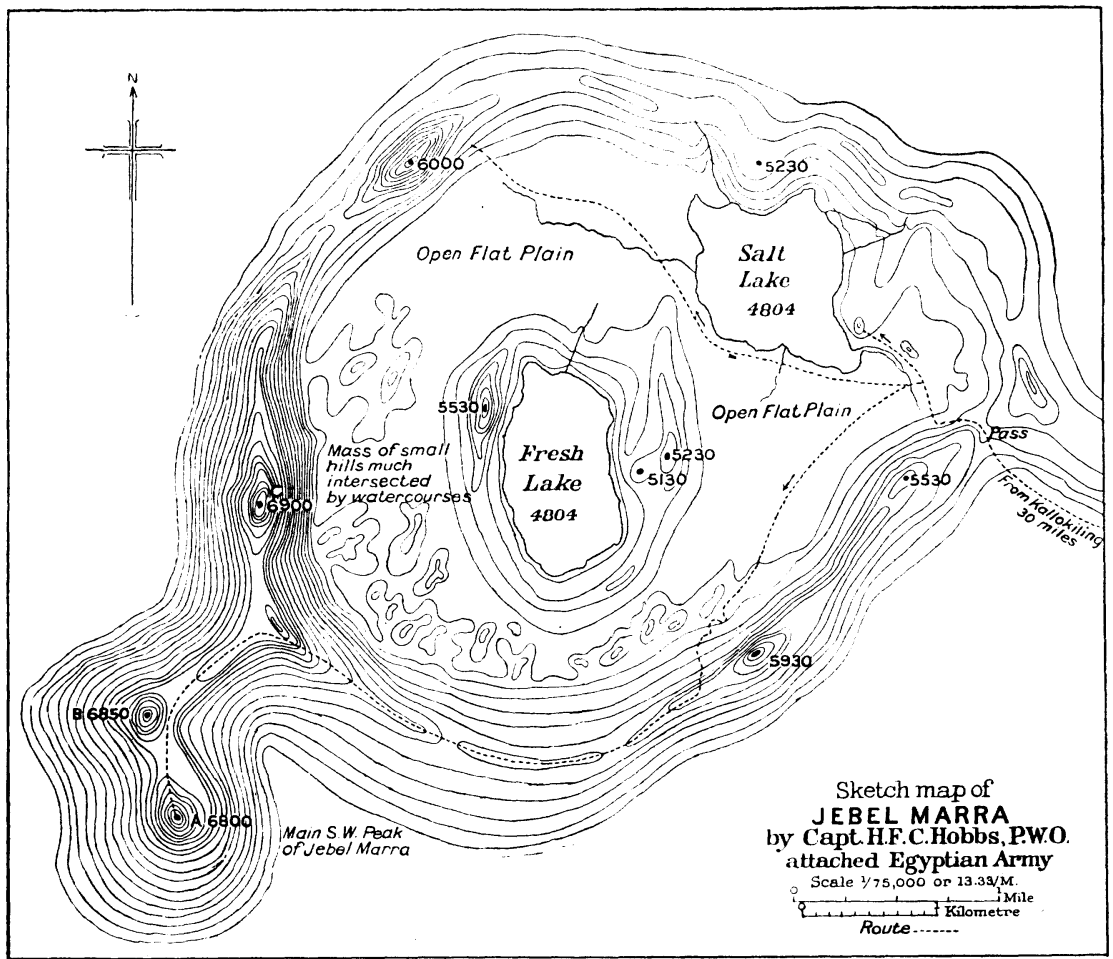

feet than the one (A) we were on ; and a third, about 20 miles distant, bearing $54^{\circ}$ magnetic, which was probably highest of all. The peak we climbed is by far the most conspicuous in the south-westerly end of the mountain, and is called by the people the "original" Jebel Marra.

Owing to the fact that my aneroid barometer was constructed to register only up to 5000 feet, I was unable to ascertain the height of the peak we climbed. The lakes registered 4804 feet above sea-level, and I should say, estimating by eye, that the peak was at least 2000 feet above them, which would make it about 6800 feet above sea-level.

We came across many traces of greater kudu on our way up the mountain, and saw two females about 600 yards off. These, and a soli- 
tary couple of golden-crested cranes on the haunted lake, were the only game we saw in the Jebel. From the peak we returned to camp at Deriba, the return journey occupying $3^{\frac{1}{2}}$ hours.

On March $\mathrm{r}_{5}$ we left Deriba, and, retracing for a few miles our path from Kallokiting, struck north-east across the mountain and eventually reached the plain near Kala village on the evening of the 2 oth. Our route from south to north-east ran over very broken and rough country, switchbacking over rocky gorges and intervening ridges. We passed many villages, considerable cultivation, and endless terracing.

The Fur build quite good tukls or circular huts with walls of loose stones and roofs well thatched with grass. The villages are in every case surrounded by loose stone walls of considerable strength and thickness, about 6 feet high, and usually topped with a breastwork of faggots. These villages are very much better and more strongly built than any others I have yet seen in northern or southern Darfur, and are in striking contrast to the miserable, ill-built hovels of the Beni Helba Baggara Arabs who inhabit the plain to the south-west of the Jebel.

The Jebel Fur are a shy, fatalistic, and credulous people of low mental development. On the other hand, they are distinctly in advance of the other tribes of Darfur as builders and cultivators, and with firm and sympathetic handling should in time develop their natural talents to a considerable extent.

I am indebted to Mr. J. A. Gillan for the small-scale sketch-map which illustrates the relative positions of the Deriba lakes and El Fasher; and to Mr. H. A. MacMichael, D.s.o., Sudan Civil Service, for reference to old maps of Jebel Marra in his possession.

El Fasher, 14 April 1918.

\section{THE GEOLOGICAL APPLICATION OF GEODETIC RESULTS}

\section{R. D. Oldham, F.R.S.}

COME criticism is so wide of the mark that it hardly calls for reply, $D$ and to this class Sir S. Burrard's note in the October number of this Journal seems to me to belong. He starts by describing my memoir as a book on geodesy written by a professional geologist; this, however, is just what it is not, nor was meant to be, on the contrary it accepts the results of geodetic work absolutely, and is an attempt to examine how far, and in what way, these results may be used in elucidating a certain limited group of purely geological problems. This distinction was set forth as clearly as possible, not without success if one may judge from the summary of the literature by Dr. Morley Davies, published in this Journal, and the review which appeared in Nature. Neither of these 